сородичей. Родовое дерево выступает в данном случае как коллективная душа рода, так как с этим деревом связываются представления о жизни и благополучии всего рода и сородичей. Понятие о родовом дереве как о коллективной родовой душе связывается также с представлениями о душах предков, в частности, о шаманских духах-предках.

Фигура шамана как личности всегда привлекала внимание ученых и путешественников, но до сих пор вызывает много споров. По вопросу, касающемуся непосредственно личности шамана, необходимо отметить точку зрения С.М. Широкогорова, который, исследуя этнопсихологический комплекс у тунгусо-маньчжурских народов, отметил отдельные случаи нервных болезней у шаманов, но при этом решительно подчеркивал физическое и психическое здоровье большинства шаманов. Он рассматривал шаманство как способ самозащиты и проявление биологических функций рода, как саморегулирующийся механизм психической сферы людей. То есть в трудах СМ. Широкогорова, высказывались идеи о шаманстве как механизме саморегулирования психоментального этнического комплекса тунгусов [Опыт исследования основ шаманства у тунгусов, 2001].

Таким образом, действительно, шаманизм является особым историко-культурным феноменом. Традиционно шаманы играли важную роль в жизни своих соплеменников, шаман является символическим посредником между миром людей и воображаемым миром душ или духов. Важнейшей характерной чертой шамана является его способность путешествовать в трансцендентальные миры и общаться в состоянии транса. В работе рассмотрен образ шамана, который рисуется в мифологии как центральная фигура Среднего мира, и которой была доступна связь со всеми тремя мирами Вселенной.

$$
* * *
$$

1. Сем Т.Ю. Шаманизм народов Сибири. Этнографические материалы ХVIII-ХХвв.: Хрестоматия / Сост., вступ. ст., исслед., прилож., заключ., подбор илл. Т. Ю, Сем. - СПб.: Филологический факультет СПбГУ, 2006. - $664 \mathrm{c}$.

2. Анисимов А.Ф. Космологические представления народов Севера. - М.-Л.: Изд-во АН СССР, 1959.108 с.

3. Опыт исследования основ шаманства у тунгусов. Публ. по изданию: Широкогоров С.М. Избранные работы и материалы. - Кн. 1. - Владивосток: Изд-во Дальневост. ун -та, 2001. 62 с.

\title{
Бейсембаева А.P. \\ Некоторые сведения о развитии торгово-хозяйственных связей на северной приграничной зоне казахских степей в XVIII веке
}

Институт Истории и этнологии им.Ч.Ч. Валиханова КН МОН РК

(Казахстан, Алматы)

doi: $10.18411 /$ trnio-12-2021-123

\section{Аннотация}

В период с конца XVIII и начала XIX века казахско-русские торговые связи постепенно набирают оборот и усиливаются при императрице Екатерине II и ее преемниках. Интерес с экономической стороны к Степным территориям в значительной степени был сосредоточен на выгодном приобретении скота и продуктов животноводства, таких как шерсть и кожа. Кочевники на сезонных ярмарках приобретали зерно и не доступные товары промышленного производства. Казахское население видело важные экономические выгоды от развития торговли и обмена со своими оседлыми соседями. Нарастание объема торговли повлекло за собой постепенное увеличение спроса и предложений на рынке, притяжение человеческих ресурсов в торговые центры, усиление процесса оседания казахов в результате перемещения кочевок ближе к северным районам.

Ключевые слова: история, Казахские ханства, Российская империя, Средний жуз, султаны, торговля, экономика, хозяйство. 


\section{Abstract}

Kazakh-Russian trade relations are gradually gaining momentum and strengthening under the Empress Catherine II and her successors in the period from the end of the 18th and the beginning of the 19th century. Economic interest in the Steppe territories was largely focused on the profitable acquisition of livestock and livestock products, these were wool and leather. Nomads purchased grain and unaffordable manufactured goods at seasonal fairs. The Kazakh population saw important economic benefits from the development of trade and exchange with their sedentary neighbors. The increase in the volume of trade entailed a gradual increase in demand and supply in the market, the attraction of human resources to shopping centers, an intensification of the process of settling of the Kazakhs as a result of the movement of migrations closer to the northern regions.

Keywords: history, Kazakh Khanates, Russian Empire, Middle Zhuz, sultans, trade, economy, household.

В XVIII веке Российская империя создала ряд фортов в Сибири вдоль северного Дешт-и-Кипчака, которые стали торговыми центрами для казахов Среднего жуза. Основными из них вдоль укрепленной линии были Троицк, Петропавловск и Семипалатинск. Они связаны рядом аванпостов, в которых жили казачьи отряды, в основном из сибирских и оренбургских казаков. В середине XVIII века торговля с казахами Среднего жуза имела небольшой товарооборот и проходила в основном через Троицк. Восточно-туркестанские купцы поставляли казахам большое количество хлопчатобумажных тканей, шелка, посуду, фрукты, ковры, оружие, хлеб и рис. Казахи также осуществляли функции посредников между Цинской и Российской империями, частично в сотрудничестве с кокандцами, ташкентцами или бухарцами.

Подавляющее большинство казахов XVIII занимались кочевым скотоводством. Огромные стада, у баев, и даже у самого бедного - было свое стадо - резерв благосостояния. Ч. Ч. Валиханов считал, что казахи XVIII века были гораздо богаче по сравнению с финансовым состоянием в середине XIX века: «стоит только посмотреть на численность скота, который был пригоняем на оренбургскую и сибирскую линии в конце прошлого и в начале нынешнего столетия, и на официальные исчисления 20-30-х гг. В эту последнюю эпоху было немало киргиз, имевших 10-тысячные табуны лошадей» [1, с. 106-107]. Лошади играли важную роль в жизни казахов, для которых эти благородные животные издревле представляли наибольшую ценность.

Скот круглый год находился на подножном корму. Следуя маршрутам кочеваний и сменяя пастбищные угодья кочевники передвигались по обширным степям зимой на южной части Центральной Азии, летом в степях Казахстана: «От скотоводства имеют они пропитание, и все для себя нужное посредством собственного изделия или мены с Россией, китайцами, Бухарией, Ташкендом и другими народами на вещи, коих они сами не производят. Ловля лисиц и зайцев, большей частью чрез приученых беркутов, также приносит им нарочитую пользу» [2, с. 2145-2147]. Кочевья Среднего жуза были больше связаны с территорией Туркестана, Восточной Бухары и Самарканда, а также долиной реки Талас. Летние пастбища Младшего и Среднего жузов располагались в Сарыарке - Северной, Западной и Центральной частях Казахстана.

Российская империя становится главным торговым партнером казахов в конце XVIII и начале XIX века. При Екатерине Великой (1762-1796) и ее преемниках Российская империя укрепила свои позиции на казахских территориях, хотя царская власть косвенно осуществлялась представителями региональной элиты. Экономический интерес царизма к Степным территориям в значительной степени были ориентированы на приобретение скота и продуктов животноводства, таких как шерсть и кожа. Кочевники приобретали зерно и готовую продукцию. Царские власти открыли сезонные ярмарки в 1743 году в Оренбурге для казахов Младшего жуза, а во второй половине восемнадцатого века в Троицкой крепости для Среднего жуза, а на Семипалатинской крепости для Среднего и Старого жузов. Казахское население увидело важные экономические выгоды от развития торговли и обмена со своими оседлыми соседями. В казахско-российской торговле наблюдается тенденция общего роста с 
конца 1730-х годов. Постепенное нарастание объема торговли и усиление зависимости от рынка результат влияния более развитой экономики северного соседа. Усиливается процесс оседания казахов в результате перемещения кочевок ближе к северным районам.

По словам Левшина в городах Гурьев, Уральск, Петропавловск и Семипалатинск русские закупили у казахов около 100 тысяч лошадей и 1 миллиона баранов в течение 1 года: «Надобно полагать, в цветущее время мены с казахами, ежегодно только в Оренбурге выменивали у них до 500 тысяч овец и столько же числа в других местах границы с Россией. Следовательно, в Россию всего входило в год до 1 миллиона. Число лошадей доходило в те годы иногда до 50 тысяч. Такого же количества разного скота казахи продавали Цинской империи, Бухаре, Хиве и прочим соседям. По самым общим подсчетам, во все приграничные районы казахи поставляли до 2 миллионов овец и 100 тысяч лошадей ежегодно, не считая остальных товаров» [3, с. 225]. Из Российской империи шли товары в основном ткацкого производства, в большом количестве из шел хлеб в виде зерновой пшеницы и пшеничной муки, ржи и ржаной муки, металлические изделия. К примеру от султана Среднего жуза Уали и Кулсары батыра в Петропавловскую крепость посылались письма с запросами организовать получение 200 пудов ржаной муки, это около 3276 килограмм [4, с. 29]. Империя была единственным поставщиком таких товаров, как чугунные, железные и медные котлы, таганы, топоры, мотыги, серпы, косы, ведра, ножницы и многого другого. Все это обменивались на сатовках на товары самой разной стоимости: на бурую лисицу, на железный таган 1, на 20 аршин холста, на пол кожи красной купцы могли выменять соответственно лошадей -2 , лисиц - 3, волка - 1 [5, с. 535]. Наряду с этим казахи получали из Российской империи железо листовое, олово круговое, медь листовую и некоторые другие товары.

Для торговли купеческих караванов с дикими каменными киргисцами, ташкенцами, кашкарцами и индейцами, безопасного прохождения каравана необходим безопасный маршрут через земли Среднего жуза [6, с. 2-13]. В 1794 году генерал-майор Я.В.Боувер писал императрице о важности развития торговых отношений в данном регионе. Средний жуз был крайне важен для выгодной торговли Сибирской и Оренбургской линий. В этом вопросе рекомендовалось: «Во всякой же волости построить мечеть, кладбище и для жития старшине дом, а для всех киргисцов, к размножению скотоводства, и хутора, чтоб в зимнее время оне сами и их скот был в безопасности, определить также ко всякой мечете по одному из наших верноподданных татар в муллы» [7, с. 1-4]. В результате нехватки пастбищных угодий скотоводство находилось в трудном положении, стада в зимнее время страдали от недостатка корма. Казахскими султанами в степь выписывались команды землепашцев по 10-12 человек со всеми необходимыми инструментами: сохами, сошниками и прочими тому подобными, а так же рыболовы с сетями [8, с. 440-441]. Источники начала XIX века свидетельствуют о наличии орошаемого земледелия как в южных, так и в центральных регионах казахских земель (на склонах Каратау, вдоль рек Чу и Сырдарьи, а также в очагах поливного земледелия в центральных степях). Левшин писал о сельском хозяйстве в Западном Казахстане; он сослался на казахские пашни, существовавшие у реки Иргиз (приток Тургая). На Мангышлаке очевидцы указали на посев зерна и наличие арбузных и тыквенных полей (бахчевые культуры)

Таким образом, некоторые жители занимались заготовлением сена, принимались за изучение земледелия у русских переселенцев, занимались строительством построек для перезимовки в пределах крестьянских поселений.

Статья подготовлена в рамках реализачии проекта ИРН АР08052271 «Новые рассекреченные российские архивы о неизвестных страниџах жизни и деятельности казахских ханов, султанов, батыров (XVIII-первая половина XIX вв.».

$$
* * *
$$

1. Валиханов Ч. Ч. Собрание сочинений в пяти томах. Том 4. - Алма-Ата: Главная редакция Казахской советской энциклопедии. 1985. - 460 с.

2. АВПРИ, ф. Гл. архив, П-33, д. 8, лл. 2119-2127, 2145-2147 
3. Левшин, Алексей Ираклиевич. Описание киргиз-казачьих, или киргиз-кайсацких орд и степей. - СПб.: Карла Крайя, 1832. -264 с

4. ГИАОО. Ф. 1. Оп. 1. Д. 184. Л. 29.

5. ГИАОО Ф. 1. Оп. 1. Д. 116. Л. 535-535 об.

6. АВПРИ. Ф. Киргиз-кайсацкие дела (Средняя орда). Оп. 122/3. 1794 г. Д. 3. Л. 2-13 об.

7. АВПРИ. Ф. Киргиз-кайсацкие дела. Оп. 122/3. 1794 г. Д. 2. Л. 1-4 об.

8. ГИАОО Ф. 1. Оп. 1. Д. 116. Л. 440-441 об.

\section{Камбиев А.М. \\ Гражданская война и интервенция на Северном Кавказе (июнь - декабрь 1918 г.)}

Санкт-Петербургский государственный университет аэрокосмического приборостроения (Россия, Санкт-Петербург)

doi: 10.18411/trnio-12-2021-124

\section{Аннотация}

В статье рассматривается проблематика, связанная с Гражданской войной и интервенцией на территории Северного Кавказа во второй половине 1918 г. Дается характеристика антибольшевистским силам на Северном Кавказе, анализируется обстановка накануне 2-го Кубанского похода, во время Терского восстания и господства сил Л.Ф. Бичерахова на территории Дагестана. Отдельно разбирается тематика, связанная с борьбой Добровольческой армии на Северном Кавказе, разгрому Советской власти в регионе и противостоянию с деятелями Горской республики.

Ключевые слова: революция, гражданская война, Терек, Дагестан, Северный Кавказа, белогвардейцы, терское казачество, горцы.

\section{Abstract}

The article deals with the problems related to the Civil War and the intervention in the North Caucasus in the second half of 1918. The characteristic of the anti-Bolshevik forces in the North Caucasus is given, the situation on the eve of the 2nd Kuban campaign, during the Terek uprising and the domination of L.F. Bicherakhov's forces in Dagestan is analyzed. The topics related to the struggle of the Volunteer Army in the North Caucasus, the defeat of Soviet power in the region and the confrontation with the leaders of the Mountain Republic are discussed separately.

Keywords: revolution, civil war, Terek, Dagestan, North Caucasus, White Guards, Terek Cossacks, Highlanders.

На рубеже весны-лета 1918 г. территорию северной части бывшего Кавказского наместничества Российской империи сотрясали события Гражданской войны и иностранной интервенции. К июню 1918 г. на Дону в результате антиказачьей политики региональной Советской власти последняя была свергнута, во главе Вольного Дона стал атаман генерал П.Н. Краснов. Здесь же в апреле с юга появилась Добровольческая армия во главе с генералом А.И. Деникиным, в это же время на Дон с запада пришел Отряд русских добровольцев Румынского фронта под командованием полковника М.Г. Дроздовского. Практически параллельно с дроздовцами на Дону очутились немецкие войска. На юге, севере и востоке области против донцов сражались красные части. Черноморье и Кубань были под властью большевиков, в последней против антиказачьей политики также поднялись казаки. Ставрополье и Терек также были под властью большевиков. В Дагестане шла вооруженная борьба большевиков с отрядами исламистов. 11 мая 1918 г. на Батумской мирной конференции антибольшевистские деятели Терека и Дагестана создали Горскую республику, во главе которой стал А. Чермоев. Они также планировали с помощью турок вернуть свои позиции на Северном Кавказе [2, с. 70].

В июне 1918 г. ситуация на Северном Кавказе поменялась кардинально. Добровольческая армия, пополнив свои ряды отрядом полковника М.Г. Дроздовского и 